\title{
The Bumble Bees of Ukraine: Species Distribution and Floral Preferences
}

\author{
Irene B. Konovalova \\ State Museum of Natural History, National Academy of Sciences of Ukraine, Teatralna Street 18, 79008 Lviv, Ukraine
}

Correspondence should be addressed to Irene B. Konovalova, iren@museum.lviv.net

Received 4 August 2009; Accepted 11 December 2009

Academic Editor: Claus Rasmussen

Copyright ( $) 2010$ Irene B. Konovalova. This is an open access article distributed under the Creative Commons Attribution License, which permits unrestricted use, distribution, and reproduction in any medium, provided the original work is properly cited.

The bumble bees were studied in Ukraine between 2002 and 2009 under field conditions, by examining historical and recent collections and by the literature data. Forty one species are reported from the whole territory, 32 of them being recorded from the forest-steppe zone. Ten species are rare in all their habitats: B. confusus, B. distinguendus, B. fragrans, B. gerstaeckeri, B. ruderatus, B. armeniacus, $B$. mesomelas, $B$. laesus, $B$. veteranus, and $B$. cullumanus. The present persistence of the steppe species $B$. armeniacus, $B$. laesus, and B. cullumanus is restricted to the eastern part of the country, and B. fragrans - to the Crimean Peninsula. The information on distribution, abundance, habitat, and floral preferences of bumble bees is also provided.

\section{Introduction}

It is rather strange that at present so little is known in the World about the Ukrainian bumble bees, since the territory of this country lies in the middle of the European continent, bordering Poland, Slovakia, Hungary, and Romania in the west, the Republic of Belarus in the north, Russia in the east, and washed by the Black Sea and Sea of Azov in the south. In this paper we are going to enrich the knowledge on the bumble bees, which inhabit the vast range of the country landscapes.

The history of studies in the Ukrainian bumble bees embraces about 140 years. The historical records of different bumble bee species from the Ukrainian territory can be traced by the collections and the literature [1-12]. Since the late sixties to the end of the 20th century studies of bumble bees were nonexistent. Recently we have continued the research and a number of papers have been published [13-19].

For understanding the structure of bumble bee communities and for predicting persistence of any one species in certain habitat types, the distribution of different landscapes in the country should be taken into consideration.

\section{Materials and Methods}

2.1. Geographical Regions of Area Studied. The Ukrainian territory occupies the south-western part of East-European Plain, the eastern part of the Carpathians (named the Ukrainian Carpathians), and the Crimean Peninsula. The area of the country stretches almost $1300 \mathrm{~km}$ from the west to the east, and $900 \mathrm{~km}$ from the north to the south. The landscape of the flat country is quite diverse and form clear latitudinal zones: the mixed coniferous-broadleaved forest zone in the north, the forest-steppe zone in the centre, and the steppe zone in the south, which is adjacent to the costal line of the Black Sea and occupies the most part of the Crimean Peninsula (Figure 1). The landscapes of both highlands (the Ukrainian Carpathians and the Crimean Mountains) are characterized by different altitudinal zones (or belts). There is a considerable difference in natural conditions between and within zones, resulting in great diversity of floral and animal communities. The zone of the mixed coniferous-broad-leaved forests (the so-called Ukrainian Polissia) has a lowland relief with broad flooded river valleys and is characterized by high levels of ground waters and precipitation (550-650 $\mathrm{mm}$ per year), and by a 


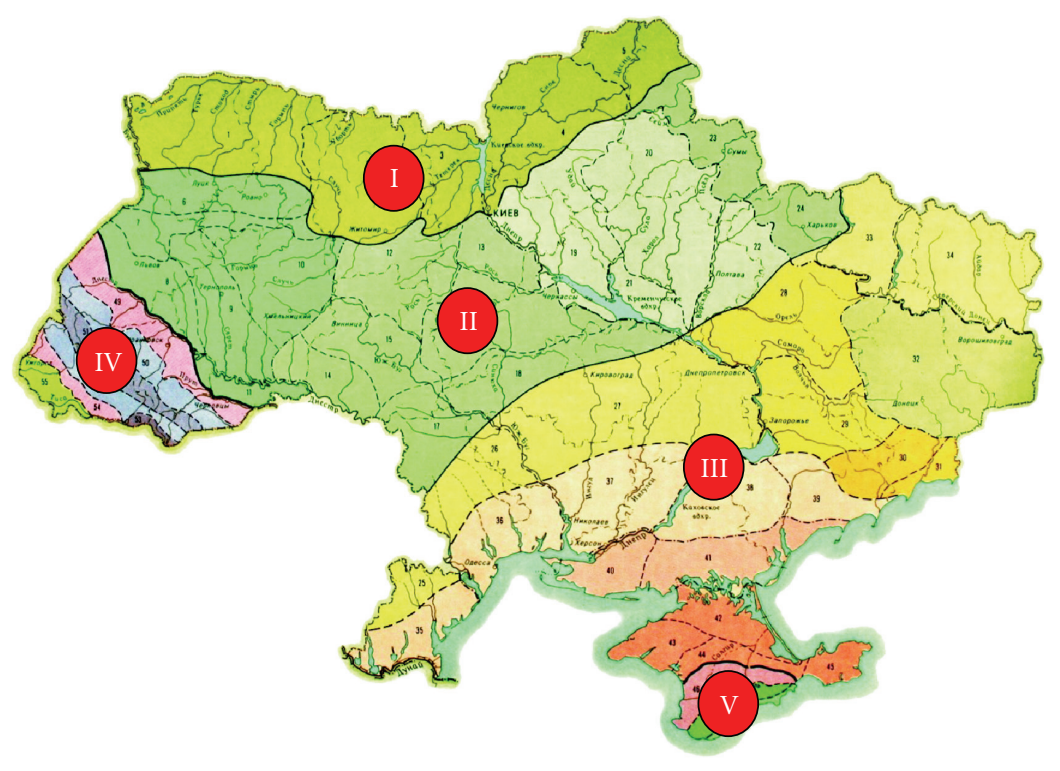

FIGURE 1: Geographical regions of Ukraine (zone limits are market in continuous line). I: the zone of mixed coniferous-broad-leaved forests; II: forest-steppe zone; III: steppe zone; IV: the Ukrainian Carpathians; V: the Crimean Mountains.

great mosaic of natural habitats. Large areas are occupied by pine forests with an admixture of broad-leaved trees. The climate is temperate continental and mild. Owing to the large areas of marshlands and boggy woodlands, unsuitable for intensive human activities, the nature of Ukrainian Polissia is the least transformed in comparison with other regions of Ukraine. The forest-steppe zone stretches from SW (the foothills of the Ukrainian Carpathians) to NE (western spurs of the Middle-Russian Hills). Eastwards the climate grows more continental. The vegetation cover has been essentially transformed; the natural forests are not available, and the steppe vegetation of natural type has been preserved in low sections of Volyn and Podolia Hills (in the west) and in the Dnieper River lowland (in the east). The steppe zone is a dry warm-temperate zone, covered mostly by grasses that decrease in forbs' diversity as one moves south. Arable land covers above $75 \%$ of the zone and little of the virgin steppe has been preserved. The Ukrainian Carpathians stretch $280 \mathrm{~km}$ long and $100 \mathrm{~km}$ wide, the highest point being Goverla Mt. (2061 m a. s. 1.). The altitudinal climatic belts are strongly pronounced, and differ in vegetation. The foothills are occupied by the broad-leaved forests (up to $600 \mathrm{~m}$ altitude), giving place to the abies-beech forests (up to 900 $1200 \mathrm{~m}$ altitude), which change into the spruce forests (up to 1400-1600 m altitude). The highest elevations are occupied by the subalpine and Alpine meadows. The inversion of altitudinal belts is often present, depending on elevation, the slope exposition, and climatic conditions. To the southwest of the Ukrainian Carpathians the Transcarpathians' Lowland lies (Figure 1), with an absolute altitude of 102$120 \mathrm{~m}$. The plain landscapes are covered with the oak and black-alder forests ( $15 \%$ of the whole area) and with small remnants of the meadow-steppe vegetation. The climate is warm and moist (precipitation about $700 \mathrm{~mm}$ per year). The lowland is densely populated and arable land covers $50 \%$.
The Crimean Mountains occupy the southern part of the Crimean Peninsula and stretch for $150-160 \mathrm{~km}$, being 50 $60 \mathrm{~km}$ wide. They are covered with dry forests of the different type and with the steppe meadows.

2.2. Sampling Localities. Bumble bees were collected regularly in all habitat types of the western Ukraine between 2002 and 2009. The bumble bee communities of the Crimea and of the eastern part of the forest zone were studied in 2006. The material from the steppe zone was collected by our colleagues during 2005-2008 and kindly placed at our disposal. The permanent monitoring of the bumble bee communities was accomplished in marshlands and marshy woodlands of Western Polissia, in protected areas within the forest-steppe zone in the west, in mixed forests and meadows of the Nature Reserve "Roztochia," in the different habitats of all altitudinal belts of the Ukrainian Carpathians and in the Transcarpathians' Lowland. The agricultural landscapes were regularly investigated as well. The bumble bees were observed on flowers and identified in field conditions, with part of them being captured for precise identification. Forage plant species were identified as well. The community structure, species relationships, foraging activities, abundance, and phenology of every species were studied throughout the season, from emerging the queens from hibernation to the last available males in autumn.

2.3. Studied Collections. We have thoroughly examined the historical and recent collections in Ukraine and housed at State Museum of Natural History and National University in Lviv, national universities in Nizyn, Uzhgorod, Simferopol, Kharkiv, Donetsk, Institute of Zoology (Kyiv), and at Kharkiv Entomological Society. As well as the bumble bee collections once made from the Ukrainian territory and 
now deposited in Russia (Zoological Museum of Moscow State University, Zoological Institute in Saint-Petersburg, and Belgorod State University) and Poland (Institute of Systematics and Evolution of Animals in Krakow). In total 10000 bumble bee specimens were examined.

\section{Results and Discussion}

3.1. Distribution and Habitat Preferences. The complete checklist of the Ukrainian bumble bees includes 41 species (Table 1). The subgenus Thoracobombus is the most representative in Ukraine and embraces 12 species. Four of them, B. pascuorum, B. humilis, B. muscorum, B. sylvarum, are widely distributed almost all over the country. $B$. pascuorum is a eurytopic species, which is capable of persistence in different conditions, including the high pressure of urban habitats [19]. In steppe zone it inhabits mainly urban and rural areas, where it can find suitable nesting sites and sufficient feeding resources. $B$. humilis is distributed mainly in the eastern part of the forest zone, all over the foreststeppe zone, and sparsely in the steppe zone, preferring dry meadows with steppe flowering vegetation. In general, its abundance everywhere is low, with the exception of the Crimean foothills and mountains. This species also occurs from foothills to about $1000 \mathrm{~m}$ altitude in the Ukrainian Carpathians, where it is rare. B. muscorum is the common inhabitant of the marshlands in Western Polissia (the forest zone), where it dominates. However, eastwards and southwards its abundance decreases rapidly, and it can be found locally in small numbers. The species avoids large swamps and flooded woodlands, as well as dry meadows, where it apparently cannot find appropriate nesting sites and feeding plants. Its foraging range is too small for searching feeding resources elsewhere than the nesting site [20]. The persistence of $B$. muscorum in the steppe zone (including the Crimea) is restricted to small natural or artificial moist "oases," and in the Ukrainian Carpathians to foothills. On the contrary, B. sylvarum prefers more dry habitats and its abundance in the forest-steppe zone is higher than in the forest zone. It also occurs in steppes, excluding arid regions.

Out of 26 bumble bee species inhabiting the forest zone (Table 1), four can be regarded as "strictly" forest species: B. hypnorum, B. jonellus, B. pratorum and B. schrencki. The boreal species $B$. jonellus, and $B$. schrencki occur all over the mixed-forest zone. Their largest populations are restricted to the western part of the zone (Rivne Region), where flooded woodlands and swamps with specific floral resources are optimal for their persistence. A small population of $B$. jonellus occurs in the west of the forest-steppe zone near Lviv City in marshy area with numerous fish-breeding ponds. We failed to find this species in the Ukrainian Carpathians, although it has been recorded from adjacent areas in Poland [21].

The greatest number of bumble bee species was recorded in the landscapes of the forest-steppe zone till the half of the 20th century (Table 1). No wonder that both forest and steppe species could find there a diverse number of habitats appropriate for their existence. Thus, "strictly" steppe species
B. fragrans, B. cullumanus (subspecies serrisquama Morawitz, 1888), B. armeniacus, and B. laesus previously were recorded in a series of localities all over the forest-steppe zone (Figures 2 and 3). At present all of them apparently extinct from the zone. Although, there are several nature reserves within the zone, protected steppe plots are too small for persistence of steppe species populations.

As for B. distinguendus and B. subterraneus, which have been included in the Species' Red Lists of many European countries as very threatened or extinct [22, 23], their distribution in Ukraine and in the forest-steppe zone in particular, is almost within the same ranges, as was recorded in the past century. Their populations are small and sparsely distributed, especially of $B$. distinguendus. It is noteworthy, that these species were considered as rare ones more than 100 years ago, at least in the west of Ukraine [1-3, 5]. Both species prefer broad meadows, with $B$. distinguendus being restricted to the northern half of Ukraine and B. subterraneus being more abundant southwards. The largest population of the latter species exists in the Crimean Mountains, including foothills [18].

The occurrence of $B$. semenoviellus in Ukraine has been reported only recently $[14,24]$. It has been considered that this species extended its range from East towards Western Europe at the end of the 20th century [25]. At least, any specimen has not been available in the historical collections of Ukraine. At present it is distributed in the forest and the forest-steppe zones with low numbers being abundant in few localities. Its persistence is connected with wetlands.

The steppe zone of Ukraine is inhabited by 22 bumble bee species (Table 1), among which are "strictly" steppe species and those with wide ecological valence, tolerant to dry and warm conditions. As well, some species of woodlands have adapted themselves to urban and rural habitats, with proper microclimate. The only steppe species, which is considered as common in the steppe zone, including the Crimean steppe, is B. argillaceus. In the forest-steppe zone it has been extinct from many localities, especially in the west. It is noteworthy that recently we have recorded B. argillaceus from the Transcarpathians' Lowland [17].

Other steppe species, B. armeniacus, B. laesus, B. zonatus, B. cullumanus, B. mesomelas, are rare in all their habitats, and nowadays persist mainly in pristine steppe areas, preserved in the east of the country. As far back as the beginning of the 20th century, B. cullumanus was considered an extremely rare species in the west of Ukraine, where it inhabited the steppe meadows in the Dnister River valley [2, 7]. We failed to confirm its persistence in the same area at present. Recently, a few specimens of the species were recorded only from the eastern part of the steppe zone (Figure 3 ). The recent populations of $B$. armeniacus persist in the Crimean steppe [18] and in the Ukrainian Steppe Reserve in the east (Figure 2).

At present, the availability of the rare species $B$. fragrans in Ukraine remains in question. Till the first half of the 20th century this species was widely distributed all over the foreststeppe and steppe zones (Figure 2). The only area, from which the species records were made in the second half of the 20th century, was the Crimean steppe [18] (Figure 2). 
TABLE 1: Bumble bees of Ukraine and their distribution among geographical zones.

\begin{tabular}{|c|c|c|c|c|}
\hline \multirow{2}{*}{ Species } & \multicolumn{4}{|c|}{ Distribution } \\
\hline & Mixed-forest zone & Forest-steppe zone & Steppe zone & Restricted to \\
\hline B. (Bi.) confusus Schenck, 1859 & • & $\bullet$ & & \\
\hline B. $(K l$.$) soroeensis (Fabricius, 1777)$ & - & • & & \\
\hline B. (St.) distinguendus Morawitz, 1869 & - & • & & \\
\hline B. (St.) fragrans (Pallas, 1771) & & $\bullet$ & - & \\
\hline B. (St.) subterraneus (Linnaeus, 1758) & $\bullet$ & $\bullet$ & & \\
\hline B. (Mg.) argillaceus (Scopoli, 1763) & & $\bullet$ & • & \\
\hline B. (Mg.) gerstaeckeri Morawitz, 1881 & & & & The Ukrainian Carpathians \\
\hline B. (Mg.) hortorum (Linnaeus, 1761) & $\bullet$ & $\bullet$ & $\bullet$ & \\
\hline B. (Mg.) ruderatus (Fabricius, 1775) & & $\bullet$ & $\bullet$ & \\
\hline B. (Th.) armeniacus Radoszkowski, 1877 & & $\bullet$ & $\bullet$ & \\
\hline B. (Th.) mesomelas Gerstaecker, 1869 & & • & - & \\
\hline B. (Th.) pomorum (Panzer, 1805) & & $\bullet$ & & \\
\hline B. (Th.) laesus Morawitz, 1875 & & $\bullet$ & • & \\
\hline B. (Th.) humilis Illiger, 1806 & $\bullet$ & $\bullet$ & $\bullet$ & \\
\hline B. (Th.) muscorum (Linnaeus, 1758) & $\bullet$ & • & • & \\
\hline B. (Th.) pascuorum (Scopoli, 1763) & $\bullet$ & $\bullet$ & • & \\
\hline B. (Th.) ruderarius (Müller,1776) & $\bullet$ & $\bullet$ & & \\
\hline B. (Th.) schrencki Morawitz, 1881 & $\bullet$ & & & \\
\hline B. (Th.) sylvarum (Linnaeus, 1761) & $\bullet$ & $\bullet$ & $\bullet$ & \\
\hline B. (Th.) veteranus (Fabricius, 1793) & $\bullet$ & $\bullet$ & & \\
\hline B. (Th.) zonatus Smith, 1854 & & & $\bullet$ & \\
\hline B. (Ps.) barbutellus (Kirby, 1802) & $\bullet$ & $\bullet$ & $\bullet$ & \\
\hline B. (Ps.) bohemicus Seidl, 1837 & $\bullet$ & $\bullet$ & $?$ & \\
\hline B. (Ps.) campestris (Panzer, 1801) & $\bullet$ & $\bullet$ & $\bullet$ & \\
\hline B. (Ps.) maxillosus Klug in Germar, 1917 & & & $\bullet$ & \\
\hline B. (Ps.) norvegicus (Sparre-Schneider, 1918) & $\bullet$ & $\bullet$ & & \\
\hline B. (Ps.) quadricolor (Lepeletier, 1832) & $?$ & & & The Ukrainian Carpathians \\
\hline B. $($ Ps. $)$ rupestris (Fabricius, 1793) & $\bullet$ & $\bullet$ & $\bullet$ & \\
\hline B. (Ps.) sylvestris (Lepeletier, 1832) & • & $\bullet$ & & \\
\hline B. (Ps.) vestalis (Geoffroy in Fourcroy, 1785) & $\bullet$ & $\bullet$ & $\bullet$ & \\
\hline B. (Pr.) haematurus Kriechbaumer, 1870 & & & & The Crimean Peninsula \\
\hline B. (Pr.) hypnorum (Linnaeus, 1758) & $\bullet$ & $\bullet$ & $\bullet$ & \\
\hline B. (Pr.) jonellus (Kirby, 1802) & $\bullet$ & & & \\
\hline B. $($ Pr. $)$ pratorum (Linnaeus, 1761$)$ & $\bullet$ & $\bullet$ & & \\
\hline B. (Pr.) pyrenaeus Pérez, 1880 & & & & The Ukrainian Carpathians \\
\hline B. (Bo.) lucorum (Linnaeus, 1761) & $\bullet$ & $\bullet$ & $\bullet$ & \\
\hline B. (Bo.) terrestris (Linnaeus, 1758) & $\bullet$ & $\bullet$ & $\bullet$ & \\
\hline B. (Ag.) wurflenii Radoszkowski, 1859 & & & & The Ukrainian Carpathians \\
\hline B. (Ml.) lapidarius (Linnaeus, 1758) & $\bullet$ & $\bullet$ & $\bullet$ & \\
\hline B. (Cu.) cullumanus (Kirby, 1802) & & $\bullet$ & $\bullet$ & \\
\hline B. (Cu.) semenoviellus Skorikov, 1910 & $\bullet$ & $\bullet$ & & \\
\hline In total: 41 & 26 & 32 & 22 & \\
\hline
\end{tabular}

-: availability of species;

?: probability of occurrence. 


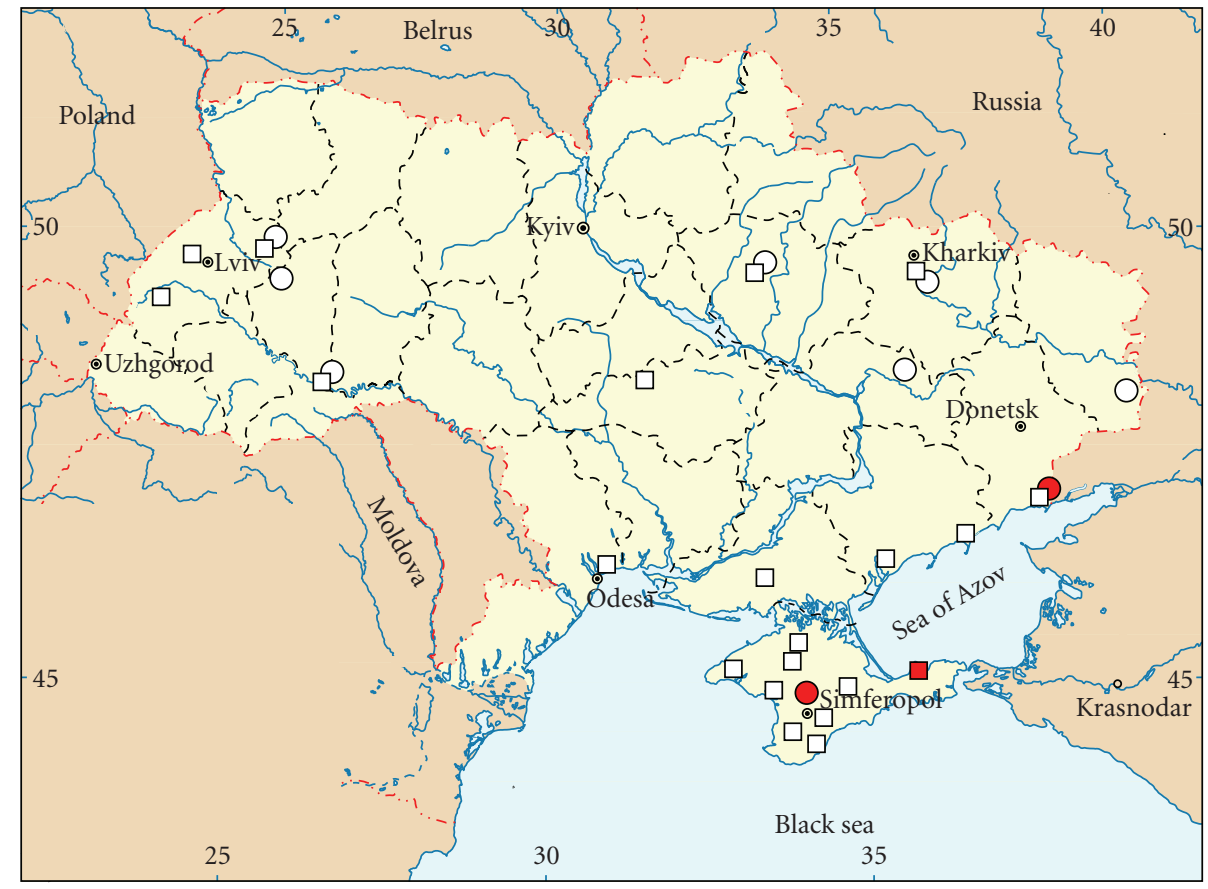

$\square$ The historical records of $B$. fragrans
$\square$ The records of $B$. fragrans within
the recent decade

The historical records of B. armeniacus

The records of $B$. armeniacus within the recent decade

Figure 2: The distribution of B. fragrans and B. armeniacus in Ukraine (the records made since 1868).

Twenty three species of bumble bees occur in the Ukrainian Carpathians [14], occupying different habitats in accordance with their ecological requirements. In general, the altitudinal distribution of bumble bees concurs with that reported from the Polish Carpathians [26]; however, some differences exist. With growing altitude the species composition of bumble bee communities changes, most of species being restricted to the upper forest limit (1400$1500 \mathrm{~m}$ alt.). B. terrestris, B. subterraneus, B. lapidarius occur up to $600-700 \mathrm{~m}$ altitude, the latter rarely rising beyond $1000 \mathrm{~m}$ in SW mountain macroslope. Only two mountain species, B. wurflenii and B. pyrenaeus, and also eurytopic $B$. lucorum founded colonies in subalpine meadows, the latter two rising to the Alpine. Although, two other species, $B$. hortorum and B. gerstaeckeri, occasionally forage in the subalpine, they never move far away from the upper forest limit. The distribution of the rare cuckoo-bee B. quadricolor remains in question, as only a single record is known from the Ukrainian Carpathians made in 1939 [8]. Recently, this species has been collected from woodlands in the Republic of Belarus, adjacent to Ukrainian Polissia (two specimens are available in the collection of Nizyn University). Hence, its existence in the forest zone of Ukraine is very likely.

About 20 bumble bee species occur in the Crimean Peninsula, which are distributed over the habitats according to their ecological preferences. The only representative of the subgenus Pyrobombus in the Crimea is B. haematurus, which occupies the niche similar to that of B. pratorum in the forest and the forest-steppe zones.

The abundances of the same species, which inhabit different landscapes or zones, are different. We try to generalize the data on a large scale of the entire territory of Ukraine (Table 2). The group "locally abundant" was created for those species, which in general can be regarded as vulnerable in Ukraine for many reasons: the occurrence near the limits of their geographical ranges, the specific habitats they need, lack of habitats due to anthropogenic influence, and so forth $[27,28]$. Only in a small number of localities all over the country these species are abundant enough.

3.2. Floral Preferences. It is known that bumble bees select the flowers fitting to the length of their tongues [29, 30]. Besides, there exists a preference for particular plant species in each bumble bee species [30-32] and in individual foragers as well [33]. These preferences change during the season, depending on plant phenology, stage of the colonial development in bumble bees, the diversity of forage plant, and on the competition in insect communities for feeding resources [30, 34]. It is also known that "majoring" and "minoring" in foraging behavior is typical of all bumble bee species [30, 35]. In Ukraine, every species of bumble bees, which occurs in different types of zonal landscapes, shows seasonal preferences to the same flowering plant species, if they are available in a habitat. Most Ukrainian bumble bees 

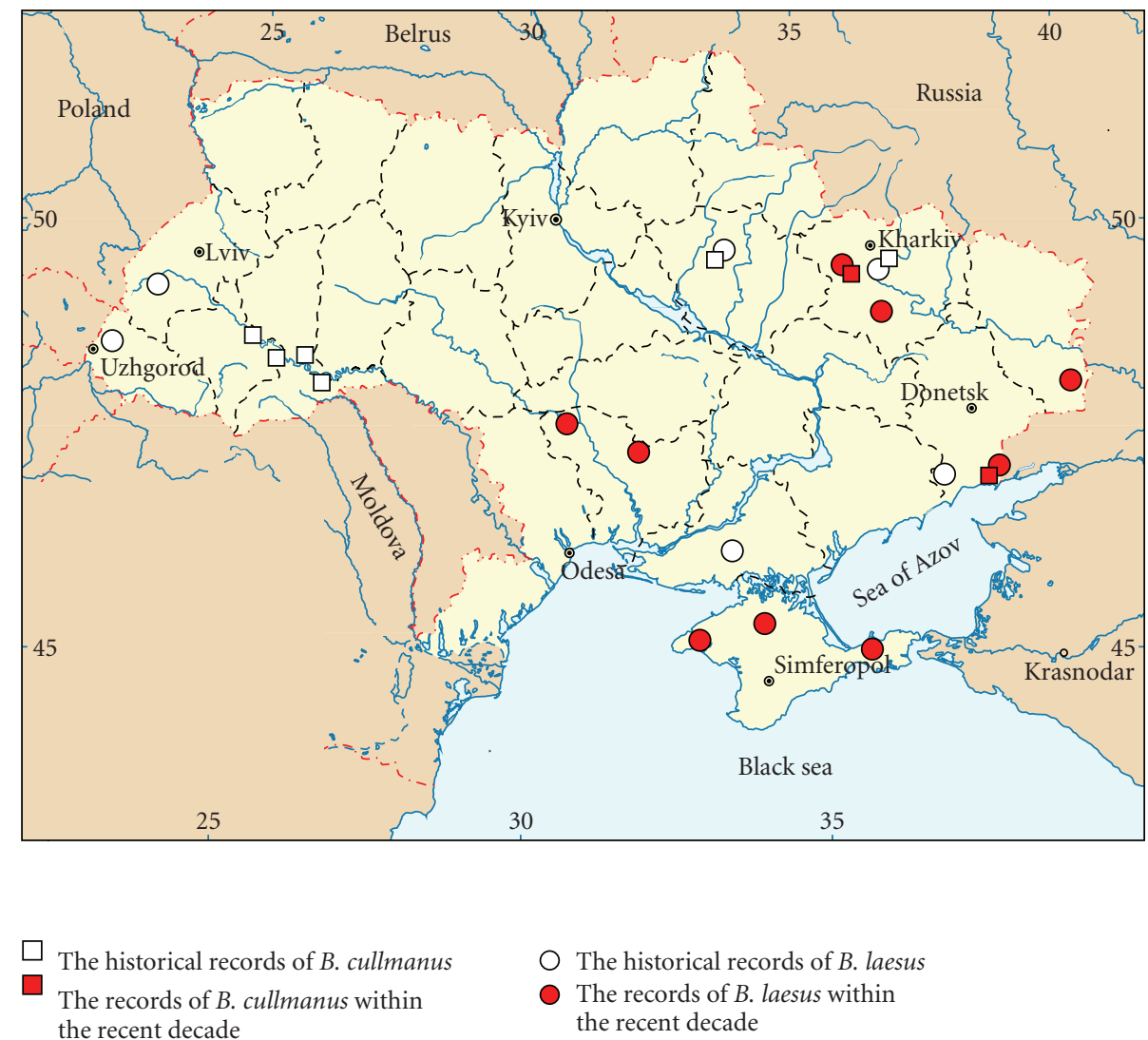
The historical records of $B$. laesus
The records of $B$. laesus within the recent decade

FIgURE 3: The distribution of B. cullumanus and B. laesus in Ukraine (the records made since 1868).

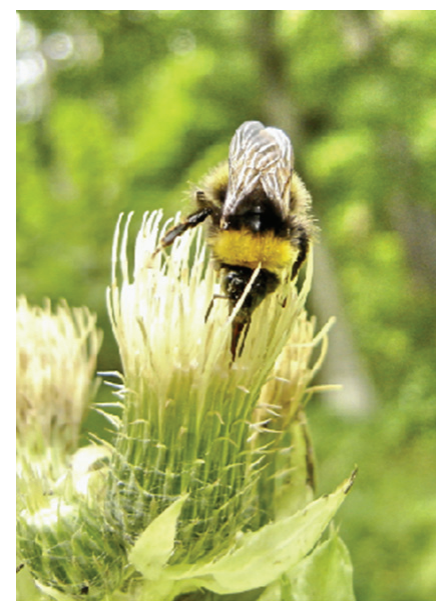

FIGURE 4: Newly emerged young queen of B. pratorum feeding on Cirsium oleraceum.

are polylectic species, with the exception of $B$. gerstaeckeri, which almost completely forages from Aconitum spp. [15], there is a difference in diet between the subgenera. The bumble bees of the subgenus Pyrobombus can be regarded as the main pollinators of Ericaceae plant species, Vaccinium myrtillus, V. uliginosum, and Rhodococcum vitis-idaea in particular. The persistence of $B$. pratorum and B. jonellus in flooded woodlands of flat country and of B. pyrenaeus

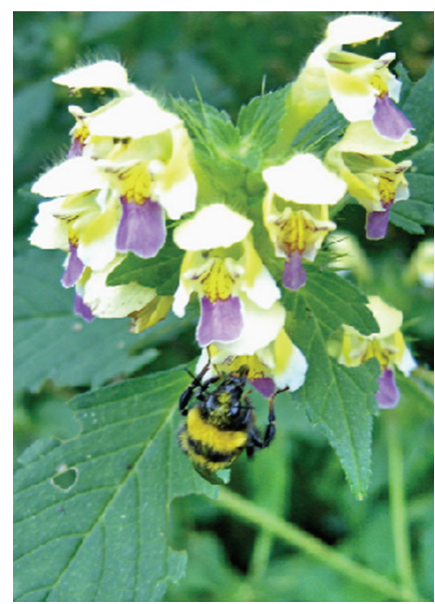

FIGURE 5: B. hortorum worker taking reward from Galeopsis speciosa flower, its favorite pant species.

in the mountains highly depends on these plants, massblooming in the crucial period of colonies' foundation. Besides, their diet always includes Geum rivale, Pulmonaria spp., and Galeobdolon luteum, Rubus spp., Frangula alnus, Symphytum spp., Geranium phaeum, Arctium spp., Cirsium spp. (Figure 4).

The long-tongued species B. hortorum (subgenus Megabombus) and the medium-tongued B. pascuorum, B. humilis, 
TABLE 2: Abundance of bumble bee species within their distributional ranges.

\begin{tabular}{|c|c|c|c|c|}
\hline Species & Rare in all their habitats & Locally abundant & Common & Ubiquitous \\
\hline B. confusus & + & & & \\
\hline B. soroeensis & & & + & \\
\hline B. distinguendus & + & & & \\
\hline B. fragrans & + & & & \\
\hline B. subterraneus & & + & & \\
\hline B. argillaceus & & & + & \\
\hline B. gerstaeckeri & + & & & \\
\hline B. hortorum & & & + & \\
\hline B. ruderatus & + & & & \\
\hline B. armeniacus & + & & & \\
\hline B. mesomelas & + & & & \\
\hline B. pomorum & & + & & \\
\hline B. laesus & + & & & \\
\hline B. humilis & & + & & \\
\hline B. muscorum & & + & & \\
\hline B. pascuorum & & & & + \\
\hline B. ruderarius & & & + & \\
\hline B. schrencki & & + & & \\
\hline B. sylvarum & & & + & \\
\hline B. veteranus & + & & & \\
\hline B. zonatus & + & & & \\
\hline B. barbutellus & & & + & \\
\hline B. bohemicus & & & & + \\
\hline B. campestris & & & & + \\
\hline B. maxillosus & & & + & \\
\hline B. norvegicus & & & + & \\
\hline B. rupestris & & & & + \\
\hline B. sylvestris & & & + & \\
\hline B. vestalis & & & & + \\
\hline B. haematurus & & & + & \\
\hline B. hypnorum & & & + & \\
\hline B. jonellus & & + & & \\
\hline B. pratorum & & & & + \\
\hline B. pyrenaeus & & & & + \\
\hline B. lucorum & & & & + \\
\hline B. terrestris & & & & + \\
\hline B. wurflenii & & & + & \\
\hline B. lapidarius & & & & + \\
\hline B. cullumanus & + & & & \\
\hline B. semenoviellus & & + & & \\
\hline In total & 11 & 7 & 12 & 10 \\
\hline
\end{tabular}

B. muscorum, B. sylvarum (Thoracobombus) everywhere prefer deep-corolla flowers of Lamium spp., Melampyrum spp., Salvia spp., Stachys spp., Vicia spp., Trifolium spp., Galeopsis spp. (Figure 5). We have observed young queens of B. muscorum feeding on Betonica officinalis inflorescences year after year in the same place at the end on July (Figure 6).

There is a number of foraging plant species, which grow abundantly everywhere, have long periods of blooming, and 


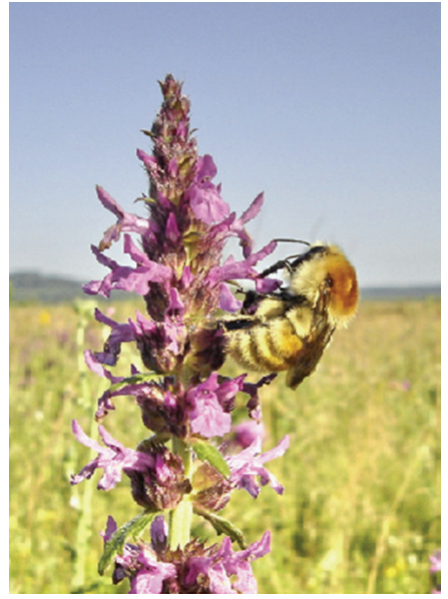

Figure 6: Newly emerged B. muscorum queen feeding on Betonica officinalis inflorescence.

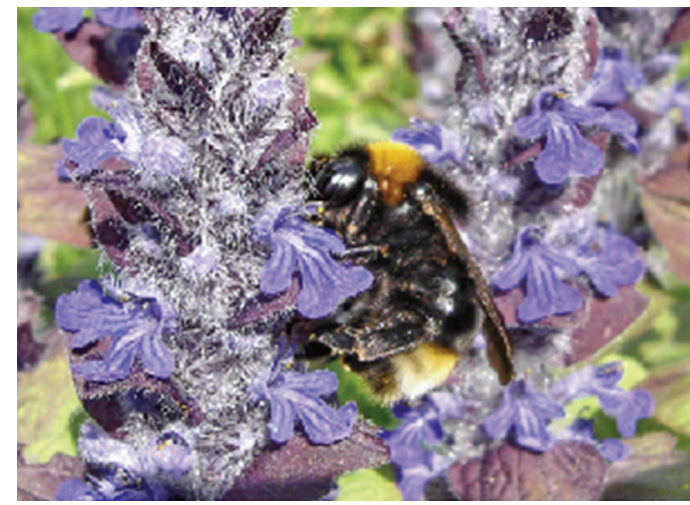

Figure 7: B. (Ps.) vestalis female feeding on Ajuga reptans.

provide much reward. In all types of habitats these plants are always preferred by bumble bees, offering great rewards to many species in crucial periods of the season. These are early spring Glechoma hederacea, Ajuga reptans, Geum rivale; late-spring Lamium spp. and Symphytum officinale; summer species Rubus idaeus, Echium vulgare, Tilia spp., Salvia verticillata, Trifolium spp., Galeopsis spp., Centaurea jacea, Circium spp., Carduus spp., Ballota ruderalis, Impatiens balsamina, and others (Figures 7 and 8).

In the west of the forest-steppe zone the major forage plants of bumble bees in summer are Trifolium spp., Salvia pratensis, S. verticillata, Betonica officinalis, and Veronica longifolia (Figures 9 and 10). In the Ukrainian Carpathians the most abundant and most preferable to bumble bees in summer are Rubus idaeus, Rubus hirtus agg., Knautia arvensis, Succisa pratensis, Carduus bicolorifolius, Cirsium waldsteinii, Chamaenerion angustifolium, Trifolium pratense, T. medium, Vicia cracca, Telekia speciosa, Centaurea jacea, and C. carpatica (Figure 11). Out of 190 forage-plant species observed in the mountains, those of the families Asteraceae (30), Lamiaceae (29), and Fabaceae (20) were particularly favored by bumble bees, making up almost $42 \%$ of the whole

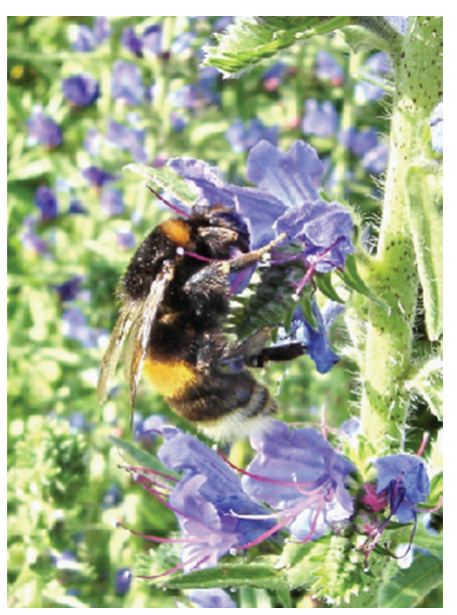

FIGURE 8: B. terrestris foudress queen foraging from Echium vulgare flower.

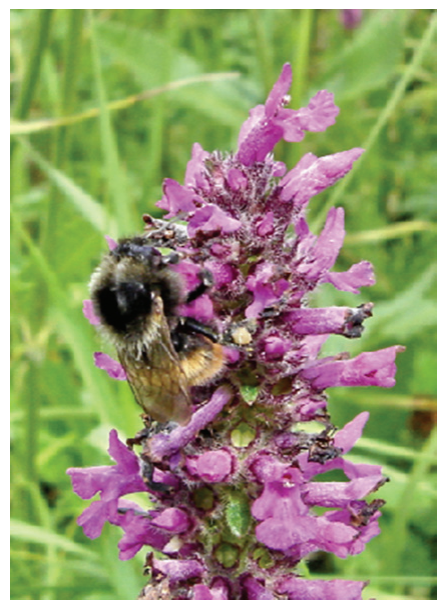

FIgURE 9: B. pomorum worker foraging from Betonica officinalis.

diet. This coincides with the results obtained in the adjacent mountain areas in Poland [36].

Studying the diet of bumble bees, inhabiting the western regions of Ukraine (Western Polissia, western part of the forest-steppe zone, and the Ukrainian Carpathians) for several years, we have recorded only those plant species, which were directly visited by foraging bumble bees. In total 352 plant species belonging to 50 families were visited, of which perennials made up $80 \%$ (282 species, including trees and shrubs). Apparently, the forage resources of bumble bees, inhabiting the whole Ukrainian area, embrace more than 500 plant species. The necessity of further research is evident.

It is beyond doubt that bumble bees are the most effective pollinators of natural and cultural flowering plants, and their declines world-wide, which have taken place during the last 50 years [28, 37-41] may have a detrimental impact on pollination networks $[42,43]$. As a result of land-use changes in the steppe zone, the steppe bumble bees have suffered a great decline both in diversity and numbers (Figures 2 and 3). As all steppe species in Ukraine occur near the northern limit of their distributional ranges, the loss of habitats or their fragmentation, and reduction in the abundance of food 


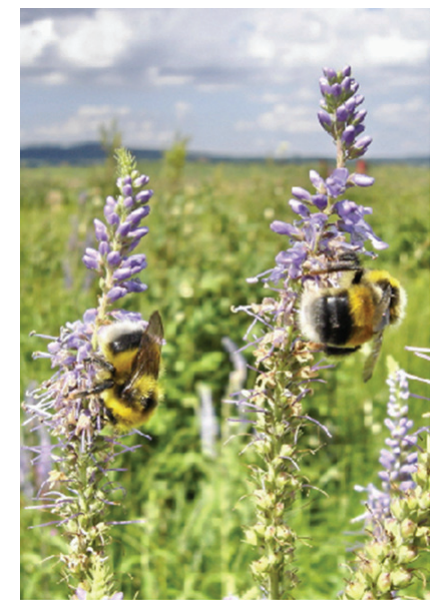

FIgure 10: Newly emerged B. lucorum males feeding on Veronica longifolia inflorescences.

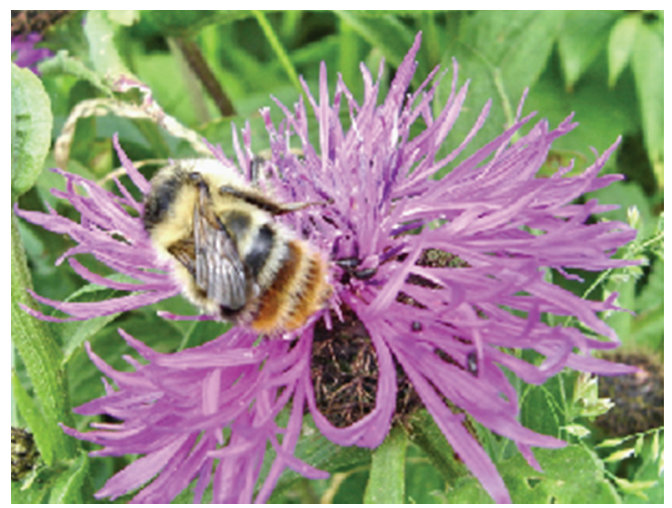

Figure 11: Young queen of B. sylvarum feeding on Centaurea carpatica.

plants have proved to be the crucial factors which caused their extinction from most localities in the forest-steppe and steppe zones of Ukraine [27, 28, 44].

Although at present there is a lack of conservation strategies in Ukraine aimed at pollinating insects, the level of agricultural industry in general is much lower than in most European countries. There are regions, especially in the forest and forest-steppe zones, and in the Ukrainian Carpathians, where the organic farming is a common practice. A lot of fallow lands and seminatural habitats enable persistence of wild bee populations. Nevertheless, the precautions should be made to prevent extinction of diverse habitats in particular cases, when large areas are set to fire in spring and autumn, what is a common practice of local people all over Ukraine. It would be useful to take advantage of the West-European countries in working out the schemes aimed at raising public awareness of the role the pollinators play both in natural and transformed ecosystems [44].

\section{Acknowledgments}

The author is much obliged to Vladimir V. Martynov for providing material from steppe reserves; to Mihail Filatov, Sergei P. Ivanov, Alexander Bokotei, Alexander N. Drogvalenko, Alexander V. Prisnyi, Waldemar Celary, Yuri
A. Pesenko, Alexander Antropov, and others for placing the bumble bee collections at her disposal; to Alexander Kuziarin for help in plant species identification; to Volodymyr B. Rizun for help in preparing illustrations.

\section{References}

[1] A. Wierzejski, "Przyczynek do fauny owadów błonkoskrzydłych (Hymenoptera)," Sprawozdania Komisyi Fizyjograficznej Akademia Umiejetnosci w Krakowie, vol. 2, pp. 108-127, 1868.

[2] A. Wierzejski, "Dodatek do fauny błonkówek," Sprawozdania Komisyi Fizyjograficznej Akademia Umiejetnosci w Krakowie, vol. 8, pp. 253-273, 1874.

[3] J. Snieżek, "O krajowych gatunkach trzmieli," Sprawozdania Komisyi Fizyjograficznej Akademia Umiejetnosci w Krakowie, vol. 29, pp. 1-22, 1894.

[4] J. Snieżek, "O krajowych gatunkach trzmielców (Psithyrus)," Sprawozdania Komisyi Fizyjograficznej Akademia Umiejetnosci w Krakowie, vol. 34, pp. 86-95, 1899.

[5] J. Snieżek, "Błonkówki pszczołowate (Apidae), zebrane w Galicyi," Sprawozdania Komisyi Fizyjograficznej Akademia Umiejetnosci w Krakowie, vol. 44, pp. 31-35, 1910.

[6] J. Noskiewicz, "Pszczołowate (Apidae) okolic Lwowa," Sprawozdania Komisyi Fizyjograficznej Akademia Umiejetnosci w Krakowie, vol. 55, no. 6, pp. 157-179, 1922.

[7] R. Kuntze and J. Noskiewicz, "Zarys zoogeofrafii polskiego Podola," Prace Nauk. TN, Lwow, vol. 2, no. 4, pp. 375-376, 1938.

[8] J. Fudakowski, W. Niesiołlowski, L. Sagan, R. Wojtusiak, and J. Zabłocki, "Drugi przyczynek do znajomosci fauny Czornohory," Instytut Badawczy Lasów Panstwowych, Rozprawy s Sprawozdania, Seria A, Warszawa, vol. 2, pp. 46-47, 1939.

[9] M. Móczár, "A dongómehek (Bombus Latr.) faunakatalógusa," Folia Entomologica Hungarica, vol. 6, no. 5, pp. 197-228, 1953.

[10] A. Z. Osychnyuk, "Bees (Apoidae) new to fauna of Ukraine," Reports of Academy of Sciences of Ukrainian SSR, no. 3, pp. 372-374, 1960 (Ukrainian).

[11] A. Z. Osychnyuk, "The landscape distribution of bees (Apoidea) in the Ukrainian Carpathians and in Transcarpathians," Works of the Institute of Zoology, vol. 16, pp. 108-117, 1961 (Ukrainian).

[12] A. Z. Osychnyuk, "“Bees (Apoidea) of the Ukrainian Polissia", Ecology and geographical distribution of invertebrates," Works of the Institute of Zoology, vol. 20, pp. 120-149, 1964 (Ukrainian).

[13] I. B. Konovalova, "Rare and threatened bumble bee species (Apodae: Bombini) in the western region of Ukraine," in Rare and Threatened Insect Species and the Concept of the Red Data Book of Ukraine, Collected Scientific Works, pp. 56-59, Kyiv, Ukraine, 2005.

[14] I. B. Konovalova, "Bumble bee fauna (Hymenoptera, Apodae, Bombus) of Western Ukraine: transformations in its structure and in the distribution of certain species," in Studies on Hymenopterous Insects, Collection of Scientific Papers, pp. 136-144, Moscow, Russia, 2007.

[15] I. Konovalova, "The first record of the rare oligolectic bumblebee Bombus gerstaeckeri Morawitz (Hymenoptera: Apidae: Bambini) from Ukraine," Annales de la Societe Entomologique de France, vol. 43, no. 4, pp. 441-443, 2007.

[16] I. B. Konovalova, "The role played by structural components of landscapes in shaping bumble bee (Hymenoptera, Apodae, Bombus) communities," in Conservation and Management of Inanimate Natural Objects in Preserved Areas, The Materials 
of International Scientific-Practical Conference, pp. 152-155, Ternopil, Ukraine, 2008.

[17] I. B. Konovalova, "The first record of Bombus argillaceus (Scopoli, 1763) (Hymenoptera, Apidae, Bombini) from the Transcarpathians' Lowland," Scientific Bulletin of the Uzhgorod University, Series Biology, no. 23, pp. 180-181, 2008.

[18] I. B. Konovalova, "Ecological-faunistic review of bumble bees Bombus Latr. (Hymenoptera: Apidae) of the Crimea," Proceedings of Kharkov Entomological Society, vol. 15, no. 1-2, pp. 131-136, 2008 (Ukrainian).

[19] I. B. Konovalova, "Urban communities of bumble bees (Hymenoptera: Apidae: Bombus) and environmental conditions need for their existence," Scientific Proceedings of Belgorod State University, Series Natural Sciences, vol. 3, pp. 81-89, 2009 (Russian).

[20] K. Walther-Hellwig and R. Frankl, "Foraging distances of Bombus muscorum, Bombus lapidarius, and Bombus terrestris (Hymenoptera, Apidae)," Journal of Insect Behavior, vol. 13, no. 2, pp. 239-246, 2000.

[21] A. Kosior, J. Fijal, W. Król, P. Płonka, A. Kalemba, and J. Korzeniak, "The bumblebees and cuckoo bees (Bombini, Apoidea) of the Western Bieszczady Mts. and the Beskid Niski Mts.," Nature Conservation, vol. 65, pp. 39-53, 2008.

[22] M. Sárospataki, J. Novák, and V. Molnár, "Assessing the threatened status of bumble bee species (Hymenoptera: Apidae) in Hungary, Central Europe," Biodiversity and Conservation, vol. 14, no. 10, pp. 2437-2446, 2005.

[23] A. Kosior, W. Celary, P. Olejniczak, et al., "The decline of the bumblebees and cuckoo bees (Hymenoptera: Apidae: Bombini) of Western and Central Europe," Oryx, vol. 41, no. 1, pp. 79-88, 2007.

[24] P. N. Sheshurak and V. L. Shevchenko, "On distribution of some insects included in Red Data Books of Ukraine and Republic of Belarus in Chernigov Region," in The Problems of Ecology and Ecological Education of Polissia in Post-Chernobyl's Period, Materials of International Conference, pp. 293-296, 2000.

[25] T. Pawlikowski, "Pszczołowate-Apidae," Klucze do Oznaczania Owadów Polski, Toruń, vol. 24, pp. 3-56, 1996.

[26] D. Goulson, G. C. Lye, and B. Darvill, "Diet breadth, coexistence and rarity in bumblebees," Biodiversity and Conservation, vol. 17, no. 13, pp. 3269-3288, 2008.

[27] P. H. Williams, "Habitat use by bumblebees (Bombus spp.)," Ecological Entomology, vol. 13, pp. 223-237, 1988.

[28] P. Williams, S. Colla, and Z. Xie, "Bumblebee vulnerability: common correlates of winners and losers across three continents," Conservation Biology, vol. 23, no. 4, pp. 931-940, 2009.

[29] E. Ranta and H. Lundberg, "Resource partitioning in bumblebees: the significance of differences in proboscis length," Oikos, vol. 35, pp. 298-302, 1980.

[30] D. Goulson, Bumblebees. Their Behaviour and Ecology, Oxford University Press, New York, NY, USA, 2003.

[31] D. W. Inouye, "Resource partitioning in bumblebees: experimental studies of foraging behavior," Ecology, vol. 59, pp. 672$678,1978$.

[32] A. Pekkarinen, "Resource partitioning and coexistence in bumblebees (Hymenoptera, Bombinae)," Annales Entomologici Fennici, vol. 50, pp. 97-107, 1984.

[33] B. Heinrich, "The foraging specializations of individual bumblebees," Ecological Monographs, vol. 46, pp. 105-128, 1976.

[34] G. H. Pyke, "Optimal foraging in bumblebees and coevolution with their plants," Oecologia, vol. 36, no. 3, pp. 281-293, 1978.
[35] B. Heinrich, “Majoring” and "minoring” by foraging bumblebees, Bombus vagans: an experimental analysis," Ecology, vol. 60, no. 2, pp. 245-255, 1979.

[36] T. Pawlikowski, M. Biliński, A. Kosior, and J. Fijał, "Site constancy of bumblebees (Hymenoptera: Apiformes: Bombus Latr.) in the habitats of two forest successional series of the Western Carpathians," Journal of Apicultural Science, vol. 51, no. 1, pp. 109-117, 2007.

[37] P. H. Williams, "The distribution and decline of British bumble bees (Bombus Latr.)," Journal of Apicultural Research, vol. 21, pp. 236-245, 1982.

[38] C. Carvell, D. B. Roy, S. M. Smart, R. F. Pywell, C. D. Preston, and D. Goulson, "Declines in forage availability for bumblebees at a national scale," Biological Conservation, vol. 132, no. 4, pp. 481-489, 2006.

[39] U. Fitzpatrick, T. E. Murray, R. J. Paxton, et al., "Rarity and decline in bumblebees-a test of causes and correlates in the Irish fauna," Biological Conservation, vol. 136, no. 2, pp. 185194, 2007.

[40] D. Goulson, M. E. Hanley, B. Darvill, and J. S. Ellis, "Biotope associations and the decline of bumblebees (Bombus spp.)," Journal of Insect Conservation, vol. 10, no. 2, pp. 95-103, 2006.

[41] D. Goulson, G. C. Lye, and B. Darvill, "Decline and conservation of bumble bees," Annual Review of Entomology, vol. 53, pp. 191-208, 2008.

[42] C. A. Kearns, D. W. Inouye, and N. M. Waser, "Endangered mutualisms: the conservation of plant-pollinator interactions," Annual Review of Ecology and Systematics, vol. 29, pp. 83-112, 1998.

[43] A.-M. Klein, B. E. Vaissière, J. H. Cane, et al., "Importance of pollinators in changing landscapes for world crops," Proceedings of the Royal Society B, vol. 274, no. 1608, pp. 303313, 2007.

[44] P. H. Williams and J. L. Osborne, "Bumblebee vulnerability and conservation world-wide," Apidologie, vol. 40, no. 3, pp. 367-387, 2009. 

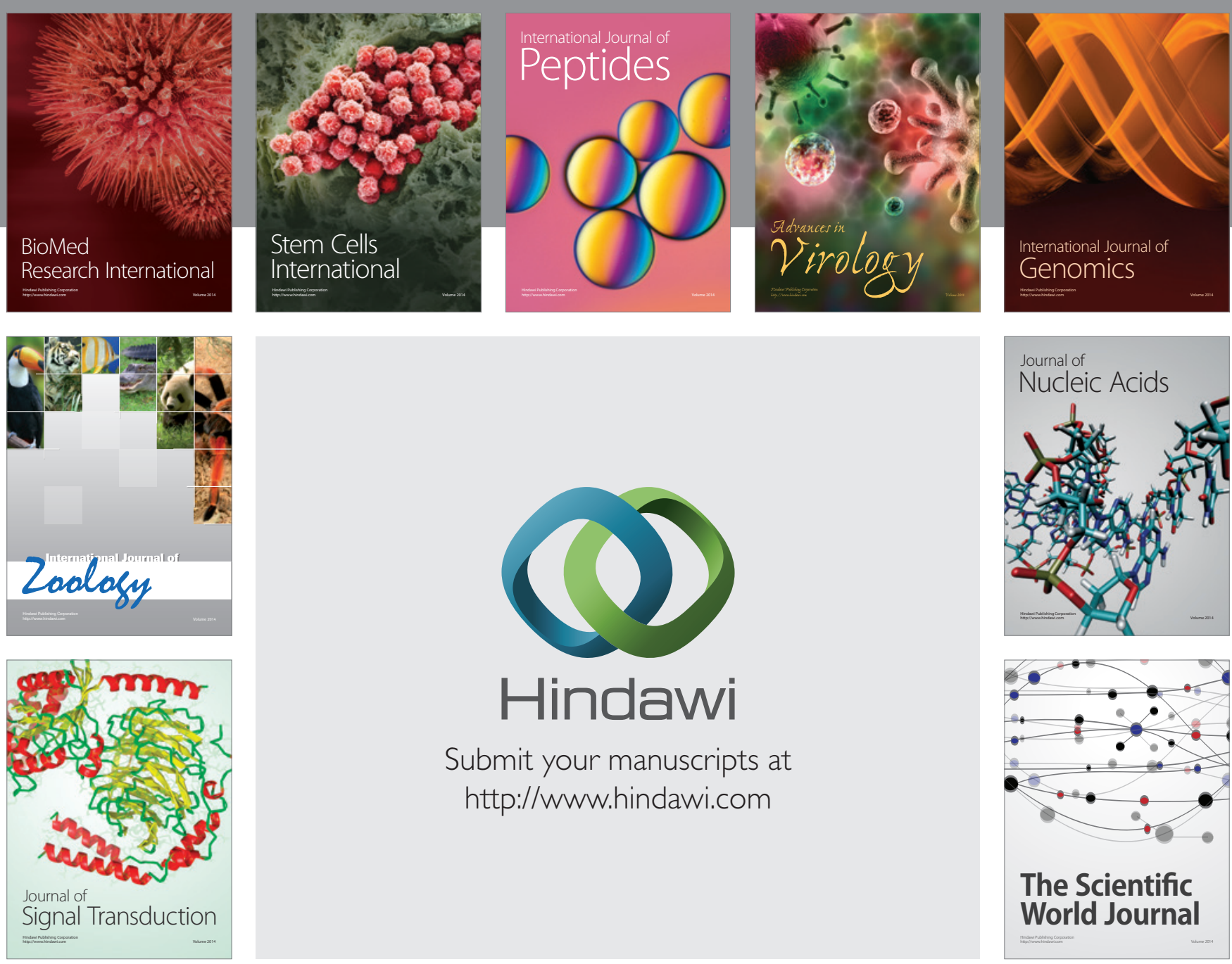

Submit your manuscripts at

http://www.hindawi.com
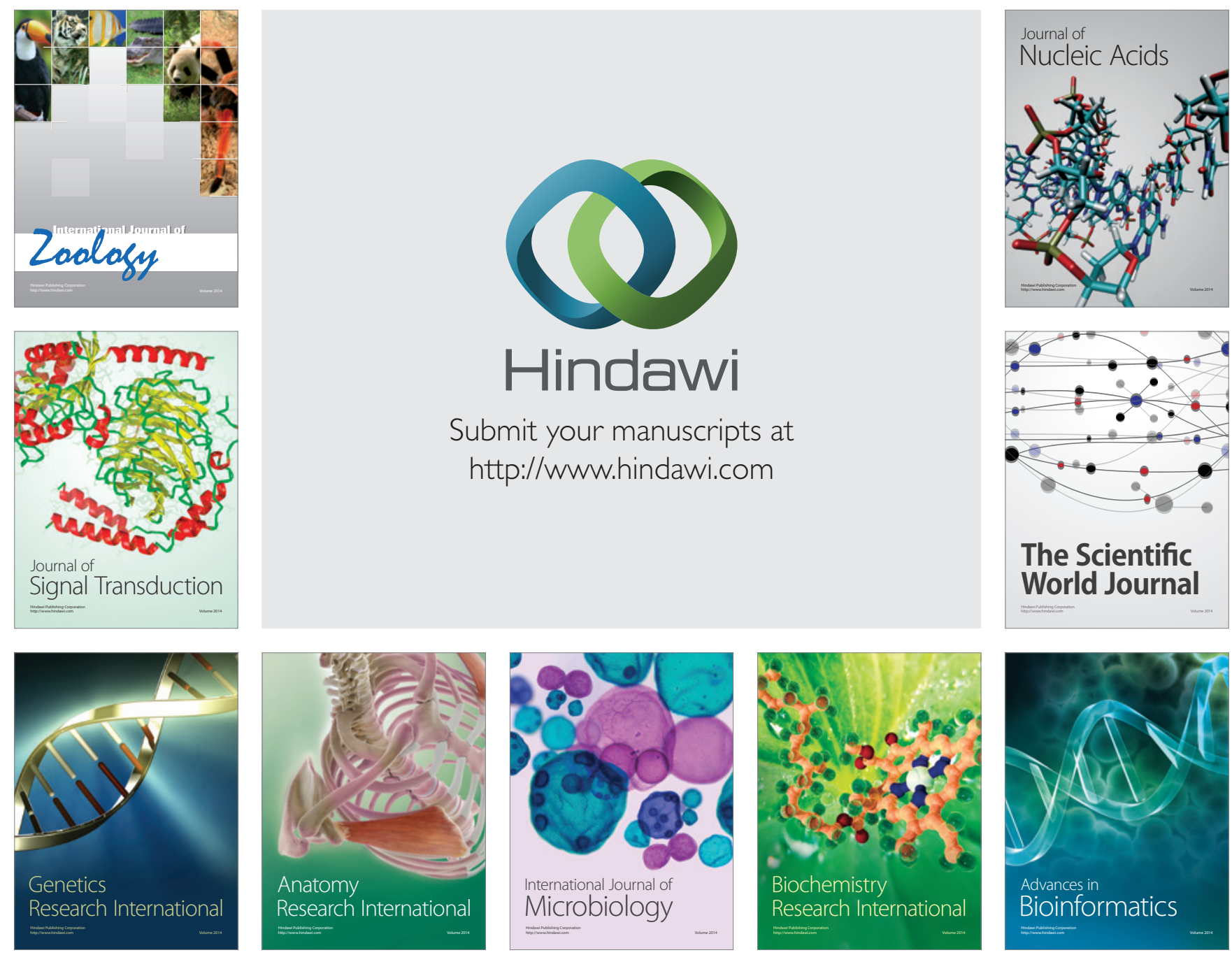

The Scientific World Journal
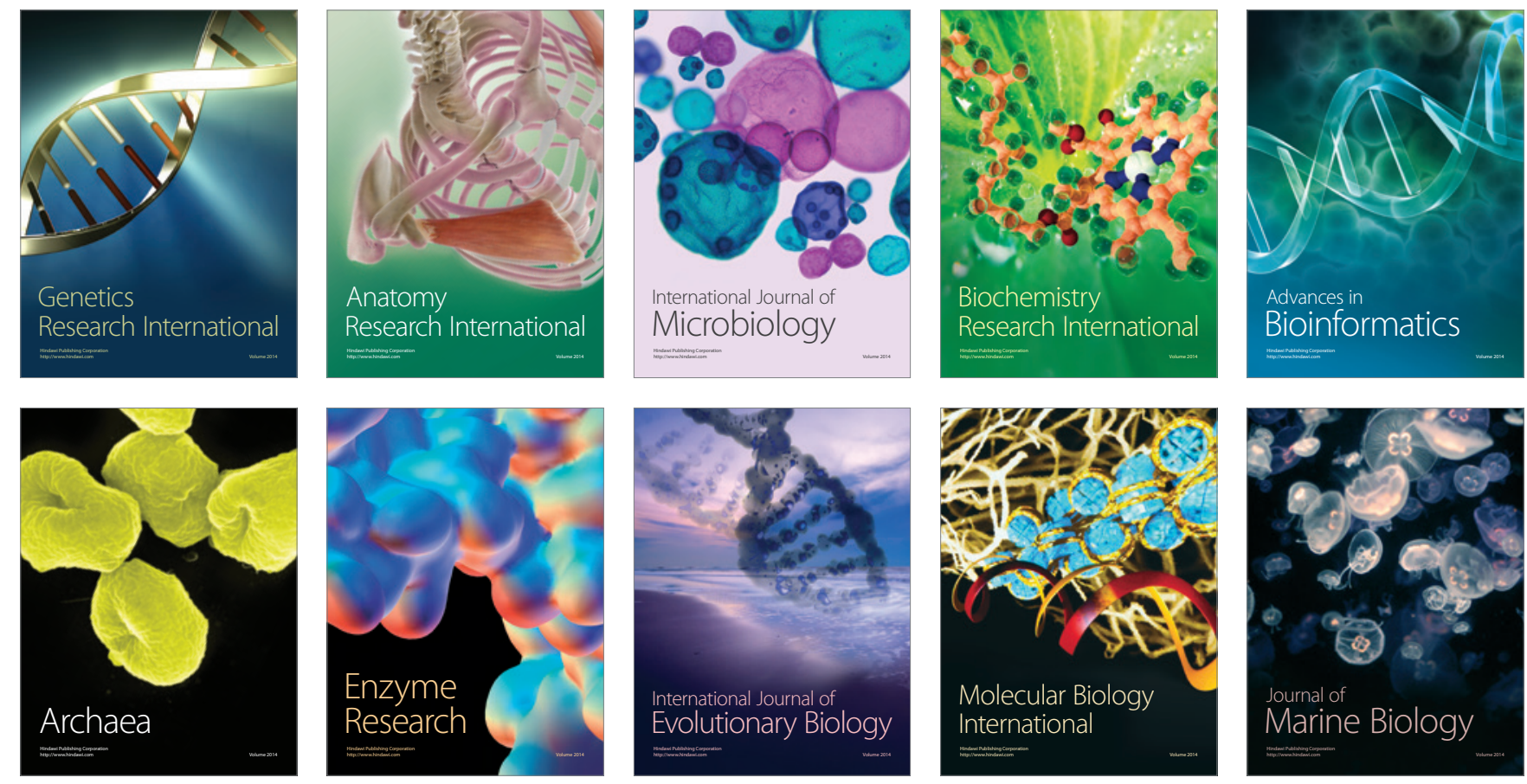